\title{
URJENSI BAHASA ARAB
}

\section{NUR ENDANG ZAINAL}

Sekolah tinggih agama islam negeri (stain) sorong, papua barat, Indonesia

Jurusan Dakwah/Program Studi Komunikasi Penyiaran Islam

Email:nurzaina10607@gmail.com

\begin{abstract}
Abstarak
Bahasa arab adalah bahasa yang tidak bisa dipisahkan dengan agama islam. Bahasa arab sering disebut bahasa islam, selain itu Al-Qur'an berbahasa arab karena ditulis dengan bahasa tersebut. Dan bahasa arab termasuk dalam bahasa resmi Islamic World League (Rabithah Alam Islami), dan Organisasi Konferensi Islam (OKI) yang beranggotakan 45 negara Islam atau negara yang mayoritas penduduknya beragama Islam. Akan tetapi, berarti bahasa ini hanya dipakai untuk umat islam. Adapun kawasan yang menggunakan bahasa arab seperti: kawasan Urubah, yakni kawasan yang meliputi 21 negara Arab yang meliputi Ara Afbrika, Arab Asia, maupun Arab Teluk yang tergabung dalam Liga Arab dan berbahasa resmi bahasa Arab, dan tidak semuanya kawasan tersebut memeluk Islam. Bahasa arab juga adalah bahasa remsi kelima dalam perserikatan bangsa-bangsa (PBB) sejak tahun 1973.selain itu juga bahasa arab dipakai sebagai persatuan bangsa Afrika OPA (Hadi, 1994: 2-3). Dengan demikian juga, bahasa arab merupakan bahasa internasional yang sering digunakan oleh bangsa-bangsa didunia. Disamping itu juga, bahasa arab dijadikan ilmu pengetahuan dan bukan hanya umat islam yang mempelajarinya, Dan jika dihitung jumlah Negara yang menggunakan bahasa arab sebagai bahasa resmi (bahasa nasional), percaya betapa luasnya Timu-Tengah dapat disebutkan, antara lain bahasa Arab adalah merupakan bahasa resmi di : Saudi Arabia, Maroko, Aljazair, Tunisia, Libia, Mesir, Sudan, Libanon, Siria, Yordania, Irak, dan Persatuan Emirat Arab (Bawani, 1997: 23). Bahasa arab tidak dapat dipisahkan dari agama islam karena sumber hukum islam adalah Al-Qur'an dan Hadtis, dan keduannya berbahasa arab..
\end{abstract}

\section{PENDAHULUAN}

Bahasa Arab (اللغة العربية) al-lughah al-'Arabīyyah, atau secara ringkas عربي 'Arabī) adalah salah satu bahasa Semitik Tengah, yang termasuk dalam rumpun bahasa Semitik dan berkerabat dengan bahasa Ibrani dan bahasa-bahasa Neo Arami. Bahasa Arab memiliki lebih banyak penutur daripada bahasabahasa lainnya dalam rumpun bahasa Semitik. Ia dituturkan oleh lebih dari 280 juta orang sebagai bahasa pertama, yang mana sebagian besar tinggal di Timur Tengah dan Afrika Utara. Bahasa arab adalah bahasa resmi dari 25 negara, dan merupakan bahasa peribadatan dalam agama Islam karena merupakan bahasa yang dipakai oleh Al-Qur'an. Berdasarkan penyebaran geografisnya, bahasa Arab adalah sebuah pembicaraan yang memiliki banyak variasi (dialek), beberapa dialeknya bahkan tidak dapat saling mengerti satu sama lain. Bahasa Arab modern telah diklasifikasikan sebagai satu makrobahasa dengan 27 
sub-bahasa dalam Bahasa Arab Baku (kadang-kadang disebut Bahasa Arab Sastra) diajarkan secara luas di sekolah dan universitas, serta digunakan di tempat kerja, pemerintahan, dan media massa.

Bahasa Arab Baku berasal dari Bahasa Arab Klasik, satu-satunya anggota rumpun bahasa Arab Utara yang saat ini masih digunakan, sebagaimana terlihat dalam inskripsi peninggalan Arab pra-Islam yang berasal dari abad ke-4. Bahasa Arab Klasik juga telah menjadi bahasa kesastraan dan bahasa peribadatan Islam sejak kurang lebih abad ke-6. Abjad Arab ditulis dari kanan ke kiri. Bahasa Arab telah memberi banyak kosakata kepada bahasa lain dari dunia Islam, sama seperti peranan Latin kepada kebanyakan bahasa Eropa. Semasa Abad Pertengahan bahasa Arab juga merupakan alat utama budaya, terutamanya dalam sains, matematik adan filsafah, yang menyebabkan banyak bahasa Eropa turut meminjam banyak kosakata dari bahasa Arab. mengawali seluruh bahan komunikasi bahasa Arab yang hendak disajikan dalam makalah ini, perlu dikemukakan sekedar penjelasan tentang duduk persoalan yang sesungguhnya dari Bahasa Arab. Tujuannya, agar para mahasiswa terhindar dari kemungkinan terjadinya salah pengertian yang menganggap kecil dan remeh akan pentingnya mempelajari Bahasa Arab. Sebaliknya, dengan pengertian yang benar maka akan tumbuh semangat dan usaha yang tak mengenal lelah untuk mempelajarinya sampai benar-benar berhasil.

\section{Pengerian Bahasa Arab Dan Pembelajaran Bahasa Arab}

Pengertian Bahasa Arab

Definisi bahasa Arab dapat ditinjau dari sisi bahasa dan istilah. Pengertian "Arab" secara bahasa adalah gurun sahara, atau tanah tandus yang di dalamnya tidak ada air dan pohon yang tumbuh di atasnya. sedangkan "bahasa" adalah alat komunikasi yang digunakan manusia untuk saling berinteraksi dan berhubungan dengan berbagai motivasi dan keperluan yang mereka miliki. Secara istilah bahasa Arab adalah bahasa yang digunakan oleh sekelompok manusia yang berdomisili di atas Negeri Gurun Sahara, Jazirah Arabiyah. Bahasa Arab merupakan bahasa Semitik dalam rumpun bahasa Afro-Asiatik dan berkerabat dengan bahasa Ibrani dan bahasa-bahasa Neo Arami yang telah dipergunakan di jazirah Arabia sejak berabad-abad. Bahasa Arab memiliki lebih banyak penutur daripada bahasa-bahasa lainnya dalam rumpun bahasa Semitik. Sekarang bahasa Arab ini di gunakan secara luas di bumi ini. Ia dituturkan oleh lebih dari 280 juta orang sebaga bahasa pertama, yang mana sebagian besar tinggal di Timur Tengah dan Afrika Utara. Bahasa Arab juga merupakan bahasa peribadatan dalam agama Islam karena merupakan bahasa yang dipakai oleh al-Qur'an yakni “sesungguhnya kami telah menjadikan al-Qur'an dalam bahasa arab, supaya kalian bisa memahaminya” (QS. Az Zukhruf:3)

\section{Keistimewaan Bahasa Arab}


1. Bahasa Arab adalah bahasa Al Quran. Allah ta'ala berfirman: "Sesungguhnya Kami telah menjadikan Al-Quran dalam bahasa Arab, supaya kalian memahaminya.” (QS. Az Zukhruf: 3).

2. Bahasa Arab adalah bahasa Nabi Muhammad dan bahasa verbal para sahabat. Hadits-hadits Nabi yang sampai kepada kita dengan berbahasa Arab. Demikian juga kitab-kitab fikih, tertulis dengan bahasa ini. Oleh karena itu, penguasaan bahasa Arab menjadi pintu gerbang dalam memahaminya.

3. Susunan kata bahasa Arab tidak banyak. Kebanyakan terdiri atas susunan tiga huruf saja. Ini akan mempermudah pemahaman dan pengucapannya.

4. Indahnya kosakata Arab. Orang yang mencermati ungkapan dan kalimat dalam bahasa Arab, ia akan merasakan sebuah ungkapan yang indah dan gamblang, tersusun dengan kata-kata yang ringkas dan padat.

\section{Hukum Mempelajari Bahasa Arab}

Syaikhul Islam Berkata: "Dan sesungguhnya bahasa Arab itu sendiri bagian dari agama dan hukum mempelajarinya adalah wajib, karena memahami Al-Kitab dan As-Sunnah itu wajib dan keduanya tidaklah bisa difahami kecuali dengan memahami bahasa Arab. Hal ini sesuai dengan kaidah:

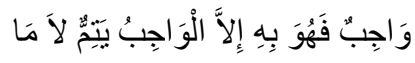

“Apa yang tidak sempurna suatu kewajiban kecuali dengannya maka ia juga hukumnya wajib.”

Namun disana ada bagian dari bahasa Arab yang wajib 'ain dan ada yang wajib kifayah. Dan hal ini sesuai dengan apa yang diriwayatkan oleh Abu Bakar bin Abi Syaibah, dari Umar bin Yazid, beliau berkata: Umar bin Khattab menulis kepada Abu Musa Al-Asy'ari (yang isinya) “...Pelajarilah AsSunnah, pelajarilah bahasa Arab dan I'roblah Al-Qur'an karena Al-Qur'an itu berbahasa Arab."

Dan pada riwayat lain, Beliau (Umar bin Khattab) berkata: "Pelajarilah bahasa Arab sesungguhnya ia termasuk bagian dari agama kalian, dan belajarlah faroidh (ilmu waris) karena sesungguhnya ia termasuk bagian dari agama kalian." (Iqtidho Shirotil Mustaqim).

\section{Keutamaan Bahasa Arab}


Tidak perlu diragukan lagi, memang sepantasnya seorang muslim mencintai bahasa Arab dan berusaha menguasainya. Allah telah menjadikan bahasa Arab sebagai bahasa Al-Qur'an karena bahasa Arab adalah bahasa yang terbaik yang pernah ada sebagaimana firman Allah ta'ala:

$$
\text { تَعْقِلُونَ لَعَلَّكُْْ عَرَبِيًَا قُرْْ آَنَا أَنْزَلْنَاهُ إِنَّا }
$$

"Sesungguhnya Kami menurunkannya berupa Al Quran dengan berbahasa Arab, agar kamu memahaminya."

Ibnu katsir berkata ketika menafsirkan surat Yusuf ayat 2 di atas: "Yang demikian itu (bahwa Al Qur'an diturunkan dalam bahasa Arab) karena bahasa Arab adalah bahasa yang paling fasih, jelas, luas, dan maknanya lebih mengena lagi cocok untuk jiwa manusia. Oleh karena itu kitab yang paling mulia (yaitu Al-Qur'an) diturunkan kepada rosul yang paling mulia (yaitu: Rosulullah), dengan bahasa yang termulia (yaitu Bahasa Arab), melalui perantara malaikat yang paling mulia (yaitu malaikat Jibril), ditambah kitab inipun diturunkan pada dataran yang paling mulia diatas muka bumi (yaitu tanah Arab), serta awal turunnya pun pada bulan yang paling mulia (yaitu Romadhan), sehingga Al-Qur an menjadi sempurna dari segala sisi." (Tafsir Ibnu Katsir, Tafsir surat Yusuf).

Syaikhul Islam Ibnu Taimiyah Berkata: "Sesungguhnya ketika Allah menurunkan kitab-Nya dan menjadikan Rasul-Nya sebagai penyampai risalah (Al-Kitab) dan Al-Hikmah (As-sunnah), serta menjadikan generasi awal agama ini berkomunikasi dengan bahasa Arab, maka tidak ada jalan lain dalam memahami dan mengetahui ajaran Islam kecuali dengan bahasa Arab. Oleh karena itu memahami bahasa Arab merupakan bagian dari agama.Keterbiasaan berkomunikasi dengan bahasa Arab mempermudah kaum muslimin memahami agama Allah dan menegakkan syi'ar-syi'ar agama ini, serta memudahkan dalam mencontoh generasi awal dari kaum Muhajirin dan Anshar dalam keseluruhan perkara mereka." (Iqtidho Shirotil Mustaqim).

Sungguh sangat menyedihkan sekali, apa yang telah menimpa kaum muslimin saat ini, hanya segelintir dari mereka yang mau mempelajari bahasa Arab dengan serius. Hal ini memang sangat wajar karena di zaman modern ini banyak sekali kaum muslimin tenggelam dalam tujuan dunia yang fana, Sehingga mereka enggan dan malas mempelajari bahasa Arab.Karena mereka tahu tidak ada hasil duniawi yang bisa diharapkan jika pandai berbahasa Arab. Berbeda dengan mempelajari bahasa Inggris, kaum muslimin di saat ini begitu semangat sekali belajar bahasa Inggris, karena mereka tahu banyak tujuan dunia yang bisa diperoleh jika pandai bahasa Inggris, sehingga kita dapati mereka rela untuk meluangkan waktu yang lama dan biaya yang banyak untuk bisa menguasai bahasa ini. Sehingga kursuskursus bahasa Inggris sangat laris dan menjamur dimana-mana walaupun dengan biaya yang tak terkira. 
Namun bagaimana dengan kursus bahasa Arab...??? seandainya mereka benar-benar yakin terhadap janji Allah ta'ala untuk orang yang menyibukkan diri untuk mencari keridhoanNya, serta yakin akan kenikmatan surga dengan kekekalannya, niscaya mereka akan berusaha keras untuk mempelajari bahasa arab. Karena ia adalah sarana yang efektif untuk memahami agama-Nya.

Kenyataan ini tidak menunjukkan larangan mempelajari bahasa Inggris ataupun lainnya. Tapi yang tercela adalah orang yang tidak memberikan porsi yang adil terhadap bahasa arab. Seyogyanya mereka juga bersemangat dan bersungguh-sungguh dalam mempelajari bahasa Arab.

Syaikh Utsaimin pernah ditanya: "Bolehkah seorang penuntut ilmu mempelajari bahasa Inggris untuk membantu dakwah ?" Beliau menjawab: “Aku berpendapat, mempelajari bahasa Inggris tidak diragukan lagi merupakan sebuah sarana. Bahasa Inggris menjadi sarana yang baik jika digunakan untuk tujuan yang baik, dan akan menjadi jelek jika digunakan untuk tujuan yang jelek. Namun yang harus dihindari adalah menjadikan bahasa Inggris sebagai pengganti bahasa Arab karena hal itu tidak boleh. Aku mendengar sebagian orang bodoh berbicara dengan bahasa Inggris sebagai pengganti bahasa Arab, bahkan sebagian mereka yang tertipu lagi mengekor (meniru-niru), mengajarkan anakanak mereka ucapan "selamat berpisah" bukan dengan bahasa kaum muslimin. Mereka mengajarkan anak-anak mereka berkata "bye-bye" ketika akan berpisah dan yang semisalnya. Mengganti bahasa Arab, bahasa Al-Qur'an dan bahasa yang paling mulia, dengan bahasa Inggris adalah haram.Adapun menggunakan bahasa Inggris sebagai sarana untuk berdakwah maka tidak diragukan lagi kebolehannya bahwa kadang-kadang hal itu bisa menjadi wajib.Walaupun aku tidak mempelajari bahasa Inggris namun aku berangan-angan mempelajarinya.terkadang aku merasa sangat perlu bahasa Inggris karena penterjemah tidak mungkin bisa mengungkapkan apa yang ada di hatiku secara sempurna." (Kitabul 'Ilmi).

Dan termasuk hal yang sangat menyedihkan, didapati seorang muslim begitu bangga jika bisa berbahasa Inggris dengan fasih namun mengenai bahasa Arab dia tidak tahu?? Kalau keadaannya sudah seperti ini bagaimana bisa diharapkan Islam maju dan jaya seperti dahulu. Bagaimana mungkin mereka bisa memahami syari'at dengan benar kalau mereka sama sekali tidak mengerti bahasa Arab 


\section{KESIMPULAN}

1. Bahasa Arab dapat ditinjau dari sisi bahasa dan istilah. Pengertian "Arab" secara bahasa adalah gurun sahara, atau tanah tandus yang di dalamnya tidak ada air dan pohon yang tumbuh di atasnya. sedangkan "bahasa" adalah alat komunikasi yang digunakan manusia untuk saling berinteraksi dan berhubungan dengan berbagai motivasi dan keperluan yang mereka miliki.

2. Keistimewaan bahasa arab ada 4 yaitu:

- Bahasa Arab adalah bahasa Al Quran. Allah ta'ala berfirman: "Sesungguhnya Kami telah menjadikan Al-Quran dalam bahasa Arab, supaya kalian memahaminya." (QS. Az Zukhruf: 3).

- Bahasa Arab adalah bahasa Nabi Muhammad dan bahasa verbal para sahabat. Haditshadits Nabi yang sampai kepada kita dengan berbahasa Arab. Demikian juga kitab-kitab fikih, tertulis dengan bahasa ini. Oleh karena itu, penguasaan bahasa Arab menjadi pintu gerbang dalam memahaminya.

- Susunan kata bahasa Arab tidak banyak. Kebanyakan terdiri atas susunan tiga huruf saja. Ini akan mempermudah pemahaman dan pengucapannya.

- Indahnya kosakata Arab. Orang yang mencermati ungkapan dan kalimat dalam bahasa Arab, ia akan merasakan sebuah ungkapan yang indah dan gamblang, tersusun dengan kata-kata yang ringkas dan padat.

3. Syaikhul Islam Berkata: "Dan sesungguhnya bahasa Arab itu sendiri bagian dari agama dan hukum mempelajarinya adalah wajib, karena memahami Al-Kitab dan As-Sunnah itu wajib dan keduanya tidaklah bisa difahami kecuali dengan memahami bahasa Arab.

4. Tidak perlu diragukan lagi, memang sepantasnya seorang muslim mencintai bahasa Arab dan berusaha menguasainya. Allah telah menjadikan bahasa Arab sebagai bahasa Al-Qur'an karena bahasa Arab adalah bahasa yang terbaik yang pernah ada sebagaimana firman Allah ta'ala:

"Sesungguhnya Kami menurunkannya berupa Al Quran dengan berbahasa Arab, agar kamu memahaminya.", 


\section{DAFTAR PUSTAKA.}

Al-Jumbulati, Ali,( 2013.) Perbandingan Pendidikan Islam, Bandung: Rineka Cipta. Arsyad, Azhar,( 2003) Bahasa Arab dan Metode Pengajarannya, Yogyakarta: Pustaka Pelajar.

Chejne, Anwar G.,(1996) Bahasa Arab dan Peranannya dalam Sejarah, terj. Aliudin Mahjudin, Jakarta: Pusat Pembinaan dan Pengembangan Bahasa.

Depertemen Agama RI, (1989) Al-Quran dan Terjemahannya, Semarang: Thoha Putra.

Hitti, Philip K., (2005) History of Arabs, Jakarta: PT Serambi Ilmu Semesta,.

Ibrah78.bahasaarab.blogspot.com. Munawwir, Ahmad Warson, Al-Munawwir, (1997) Kamus Arab-Indonesia, Yogyakarta: Pustaka Progresif.

Tafsir, Ahmad,(2012) Ilmu Pendidikan Islam, Bandung: Rosda. 